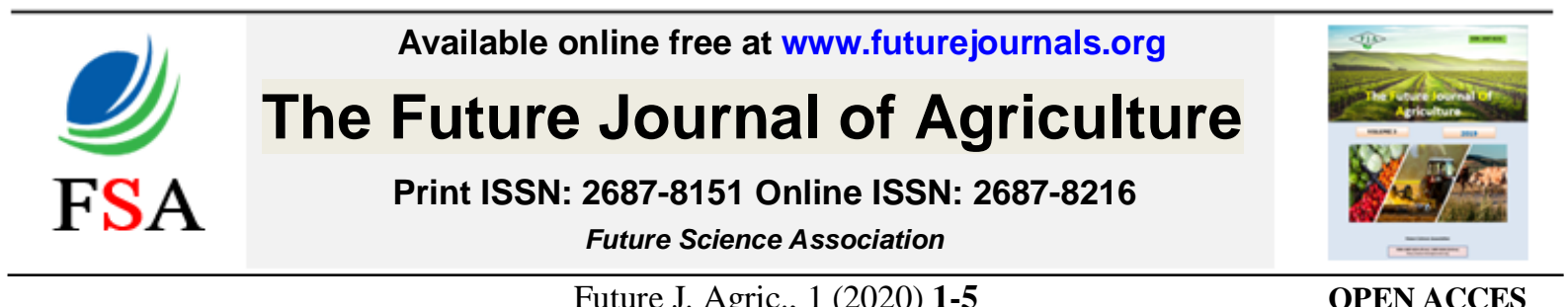

DOI: $10.37229 /$ fsa.fja.2020.01.15

Future J. Agric., 1 (2020) 1-5

OPEN ACCES

\title{
RESPONSE OF SOUR ORANGE SEEDLINGS TO APPLICATION OF GIBBERELLIC ACID AND NUTRIGREEN FERTILIZER
}

\author{
Nagham S. Salim, Ayad H. Alalaf and Ayad T. Shayal Alalam \\ Hort. \& Landscape design Dept., College of Agric. \& Forestry, Mosul Univ., Iraq.
}

*Corresponding author: Ayad_alalaf@yahoo.com

Received: 10 Dec. 2019 ； Accepted: 15 Jan. 2020

\begin{abstract}
The seedlings of Sour orange grown in plastic bags under the conditions of the Lath houses of the Horticulture Landscape design were treated with two levels of gibberellic acid (75 and $\left.100 \mathrm{mg} \mathrm{L}^{-1}\right)$ and three levels of liquid Nutrigreen fertilizer $\left(2,4\right.$ and $\left.6 \mathrm{ml} \mathrm{L}^{-1}\right)$ as well as all Interactions between them in addition to the comparison treatment in order to improve the vegetative growth of the seedlings, the study was designed according to the complete random design (CRD) by three replicates and 4 seedlings per experimental unit and used the Dunkin polynomial test at a 5\% error probability level to compare the averages of the treatments, the results confirmed the treatment of $100 \mathrm{mg} \mathrm{L}^{-1}$ of gibberellic acid $+6 \mathrm{ml} \mathrm{L}^{-1}$ of Nutrigreen fertilizer significantly outperformed the treatment of comparators as the increase in the main stem diameter and leaf content of chlorophyll, and the highest increase in seedlings length was obtained for the treatment of Nutrigreen fertilizer at a concentration of $6 \mathrm{ml} \mathrm{L}^{-1}$ while recorded treatment $100 \mathrm{mg} \mathrm{L}^{-1}$ of gibberellic acid $+4 \mathrm{ml} \mathrm{L}^{-1}$ of Nutrigreen fertilizer the highest significant increase in the number of leaves as measured by the comparison treatment.
\end{abstract}

Key words: Sour orange, seedlings, gibberellic acid, liquid organic, fertilizer.

\section{INTRODUCTION}

The origin of Citrus aurantium L. is one of the appropriate assets for most types of citrus fruits, to provide its seeds in large quantities and to deepen the root group in the soil, as well as being a good and suitable origin for lands with medium and heavy textures as it tolerates high soil moisture and inappropriate environmental conditions compared to the rest of the assets, as well. It is compatible with most citrus fruits and varieties, and it is commonly used in Iraq (Alalaf, 2019). The vegetative growth of seedlings can be improved by spraying them with appropriate levels of plant growth regulators including gibberellic acid $\left(\mathrm{GA}_{3}\right)$, as it encourages elongation of plant branches by stimulating cell division and elongation or both by stimulating the production of auxins (Hartmann et al., 2011) as it is necessary in building Nucleic acid RNA and proteins retard the demolition of chlorophyll and consequently delay the aging of leaves, and stimulate some enzymes such as -amylase $\alpha$, Protease, Esterase, etc. which have a role in the different growth processes in the plant (Hopkins and Huner, 2005).

Nutrigreen fertilizer is one of the most important liquid organic fertilizers as it contains organic nitrogen that turns into mineral nitrogen due to the microorganisms present in the soil which is absorbed by the seedlings and works to increase the building of chlorophyll (Alalaf and Shayal Alalam, 2014) and the organic carbon that enters into the synthesis of all organic 
compounds and constitutes $50 \%$ of the dry weight of most plants. It also contains organic matter, which is of great importance in improving the physical and biological properties of soil by breaking down heavy soil granules and improving their ventilation, as well as increasing the ability of the soil to retain water as well as containing 19 amino acid that increases the activity of various physiological activities in the plant, directly or indirectly through its role in forming nucleotides, vitamins, growth regulators and enzymes (Alalaf, 2019), amino acids are also involved in building cell membranes and encouraging root and chlorophyll formation (Nag et al., 2001), which is reflected in improving the efficacy of photosynthesis (Singh, 1999), many researchers including Alalaf and Shayal Alalam (2014) in their experience of fig seedlings and Al-A'areji et al. (2014) in their study of Loquat seedlings and Alalaf (2019) in their study of local grafted orange seedlings indicated that the addition of liquid nitrogen fertilizer to fruit plants led to an improvement in the vegetative and root growth characteristics of the seedlings and the leaf content of mineral elements necessary for their growth.

This study was conducted to show the importance of foliar spray with liquid organic fertilizer Nutrigreen and gibberellic acid in the vegetative growth of Sour orange seedlings to obtain good seedlings and suitable for budding in the shortest possible time.

\section{MATERIALS AND METHODS}

The study was carried out in the Lath houses of the Department the Horticulture Landscape Design / College of Agriculture and Forestry, University of Mosul, Iraq during the 2019 growing season. Sour orange seedlings were seeded with a oneyear-old seed, nearly homogeneous (height $28-30 \mathrm{~cm}$ and diameter of its main stem at a height of $5 \mathrm{~cm}$ from the soil surface $3 \mathrm{~mm}$ ) planted in polythene plastic bags (capacity of $5.00 \mathrm{~kg}$ of soil) and filled with mixture soil. Gibberellic acid was added as a spray on the vegetative system at two levels ( 75 and $100 \mathrm{mg} \mathrm{L}^{1}$ ), while liquid organic fertilizer was added to the soil Nutrigreen (its components are shown in Table 1) with three levels $\left(2,4\right.$ and $\left.6 \mathrm{ml} \mathrm{L}^{-1}\right)$ in addition to the comparison and overlap treatment between them, and so the number of transactions is 12 treatments. The seedlings were sprayed with levels of gibberellic acid with two types which are 4/15 and 5/15 until full wetness in the early morning and $1 \mathrm{~cm} \mathrm{3/5} \mathrm{liter} \mathrm{of} \mathrm{the} \mathrm{spreading} \mathrm{material} \mathrm{(20-}$ Tween) was added to the homogeneity of the solution distribution over leaves, while liquid fertilizer Nutrigreen was added in two dates $4 / 16$ and $5 / 16$ to the soil by dissolving $2 \mathrm{ml}$ of each in 1 liter of water to prepare a concentration of $2 \mathrm{ml} \mathrm{L}^{-1}$ then divide this focus on the number of seedlings in a single treatment (4) seedlings so that each seedling obtained $250 \mathrm{ml}$, as well as for the levels 4 and $6 \mathrm{ml}$.

Table 1. Components of liquid Nutrigreen fertilizer

\begin{tabular}{lc}
\hline \multicolumn{1}{c}{ Component } & percentage \\
\hline Organic nitrogen & 8.00 \\
$\begin{array}{l}\text { Organic nitrogen dissolved in } \\
\text { water }\end{array}$ & 8.00 \\
Organic carbon & 23.50 \\
That is, the total organic matter & 39.50 \\
Amino acids (19 amino acids) & 50.00 \\
$\begin{array}{l}\text { The total organic matter contained } \\
\text { in the compost }\end{array}$ & 89.50 \\
\hline
\end{tabular}

The implementation of this study was followed by a complete random design (CRD) with two factors and three replicates, using 4 seedlings per experimental unit, and thus the total number of seedlings in this study was 144 seedlings. At the beginning of October of the same season, the following characteristics were 
measured: the increase in the length of the main stem $(\mathrm{cm})$ by the tape measure, the increase in the diameter of the main stem (mm) by the foot (Vernier) and the increase in the number of leaves/ seedlings by measuring these characteristics at the beginning of the experiment And the end and record the difference between the two readings, the content of chlorophyll in the papers by the device SPAD meter (Felixloh and Bassuk, 2000).

\section{Statistical analysis}

All the obtained data were tabulated and subjected for the proper statistical analysis; by analysis of variance (ANOVA) using the statistical package SAS program (SAS, 2001). Duncan's multiple range test was used to separate treatment means to found significantly different in the analysis of variance at the level of error probability 5\%

(Duncan, 1955).

\section{RESULTS AND DISCUSSION}

The effect of foliar spray with gibberellic acid and Nutrigreen fertilizer and their interaction between the increase in the length and diameter of the main stem and the number of leaves and the chlorophyll content in the leaves for Sour orange seedlings: It is evident from the results of Table (2) that the treatment of organic fertilizer with Nutrigreen at a concentration of 6 $\mathrm{ml} \mathrm{L}^{-1}$ recorded the highest moral value as the main stem length of the seedlings amounted to $52.44 \mathrm{~cm}$, but it did not significantly outperform except the comparison treatment, which gave the lowest significant value of this trait reached $40.95 \mathrm{~cm}$, the highest significant value was obtained for the two characteristics of the increase in the main stem diameter and the leaf content of chlorophyll at $4.22 \mathrm{~mm}$ and 50.92 SPAD as a result of the treatment of $100 \mathrm{mg} \mathrm{L}^{-1}$ of gibberellic acid $+6 \mathrm{ml}$ $\mathrm{L}^{-1}$ of Nutrigreen fertilizer while the lowest values of these two attributes reached $2.92 \mathrm{~mm}$ and $38.03 \mathrm{SPAD}$ for the comparison treatment. The increase was significant as the number of sheets as a result of the treatment of $100 \mathrm{mg}$ $\mathrm{L}^{-1}$ of gibberellic acid $+4 \mathrm{ml} \mathrm{L}^{-1}$ of fertilizer Nutrigreen reaching 54.21 leaves while recorded a transaction comparison less the value of the recipe was 24.86 leaves.

The moral superiority of the treatments used is special $\left(100 \mathrm{mg} \mathrm{L}^{-1}\right.$ of gibberellic acid $+6 \mathrm{ml} \mathrm{L} \mathrm{L}^{-1}$ of Nutrigreen fertilizer) and (100 $\mathrm{mg} \mathrm{L}^{-1}$ of gibberellic acid $+4 \mathrm{ml} \mathrm{L}^{-1}$ of Nutrigreen fertilizers) and $\left(6 \mathrm{ml} \mathrm{L}^{-1}\right.$ of Nutrigreen fertilizer) with the studied characteristics may explain the importance of gibberellic acid in the division or breadth of salami cells or both and encourage cambium activity by increasing the division of cambium cells and increasing its growth in addition to stimulating some enzymes such as -amylase $\alpha$ and Protease and Esterase and others that have a role in the different growth processes in the plant (Hopkins and Huner, 2005), as it is necessary in building RNA and proteins and retarding Demolishing chlorophyll which leads to an increase in the efficiency of plant growth processes such as height and diameter of seedlings.

As for the importance of liquid organic fertilizer, Nutrigreen is due to its contain of organic nitrogen, which turns into mineral nitrogen due to the microorganisms present in the soil, which is absorbed by the seedlings as it increases the building of chlorophyll (Al-A'areji et al., 2014) as well as its role in improving Soil properties and increase the readiness of major and minor nutrients and their absorption by plant roots and thus increase their growth (Khaled and Fawy, 2011), in 
addition to containing amino acids that increase the activity of various physiological activities in the plant directly or indirectly through their role in the formation of nucleotides vitamins, growth regulators and enzymes which is an essential component of living matter and protoplasm and interference in the construction of cellular membranes and promote the formation of roots and chlorophyll, which is reflected positively in the efficiency of the optical structure (Singh, 1999) and thus improve the characteristics of the studied vegetative growth.

Table 2. Effect of adding Nutrigreen fertilizer and foliar spray with gibberellic acid and their interaction in increasing the length and diameter of the main stem and number of leaves and the content of chlorophyll in the leaves for Sour orange seedlings

\begin{tabular}{|c|c|c|c|c|}
\hline Treatments & $\begin{array}{l}\text { Length of } \\
\text { main stem } \\
\quad(\mathrm{cm})\end{array}$ & $\begin{array}{l}\text { Diameter of } \\
\text { main stem } \\
(\mathbf{m m})\end{array}$ & $\begin{array}{c}\text { Number of } \\
\text { leaves } \\
\text { (leaf/seedlings) }\end{array}$ & $\begin{array}{l}\text { Chlorophyll } \\
\text { content in the } \\
\text { SPAD leaves }\end{array}$ \\
\hline Control & $\begin{array}{c}40.95 \\
B\end{array}$ & $\begin{array}{c}2.92 \\
\mathrm{~B}\end{array}$ & $\begin{array}{c}24.86 \\
B\end{array}$ & $\begin{array}{c}38.03 \\
\mathrm{~B}\end{array}$ \\
\hline Gibberellic acid $75 \mathrm{mg} \mathrm{L}^{-1}$ & $\begin{array}{c}44.92 \\
\mathrm{AB}\end{array}$ & $\begin{array}{c}3.86 \\
\mathrm{~A}\end{array}$ & $\begin{array}{c}35.97 \\
\mathrm{AB}\end{array}$ & $\begin{array}{c}40.67 \\
\mathrm{AB}\end{array}$ \\
\hline Gibberellic acid $100 \mathrm{mg} \mathrm{L}^{-1}$ & $\begin{array}{c}48.25 \\
\mathrm{AB}\end{array}$ & $\begin{array}{c}3.72 \\
\mathrm{~A}\end{array}$ & $\begin{array}{c}39.44 \\
\mathrm{AB}\end{array}$ & $\begin{array}{l}40.23 \\
\mathrm{AB}\end{array}$ \\
\hline Nutrigreen fertilizer $2 \mathrm{ml} \mathrm{L}^{-1}$ & $\begin{array}{l}48.21 \\
\mathrm{AB}\end{array}$ & $\begin{array}{c}3.71 \\
\mathrm{~A}\end{array}$ & $\begin{array}{c}44.56 \\
\mathrm{~A}\end{array}$ & $\begin{array}{l}45.91 \\
\mathrm{AB}\end{array}$ \\
\hline Nutrigreen fertilizer $4 \mathrm{ml} \mathrm{L}^{-1}$ & $\begin{array}{c}48.00 \\
\mathrm{AB}\end{array}$ & $\begin{array}{c}3.76 \\
\mathrm{~A}\end{array}$ & $\begin{array}{c}44.24 \\
\mathrm{~A}\end{array}$ & $\begin{array}{c}46.81 \\
\mathrm{AB}\end{array}$ \\
\hline Nutrigreen fertilizer $6 \mathrm{ml} \mathrm{L}^{-1}$ & $\begin{array}{c}52.44 \\
\mathrm{~A}\end{array}$ & $\begin{array}{c}3.89 \\
\mathrm{~A}\end{array}$ & $\begin{array}{c}45.66 \\
\text { A }\end{array}$ & $\begin{array}{c}46.81 \\
\mathrm{AB}\end{array}$ \\
\hline $\begin{array}{l}\text { Gibberellic acid } 75 \mathrm{mg} \mathrm{L}^{-1}+ \\
\text { Nutrigreen fertilizer } 2 \mathrm{ml} \mathrm{L}^{-1}\end{array}$ & $\begin{array}{c}48.80 \\
\mathrm{AB}\end{array}$ & $\begin{array}{c}3.80 \\
\mathrm{~A}\end{array}$ & $\begin{array}{c}45.52 \\
\mathrm{~A}\end{array}$ & $\begin{array}{l}44.96 \\
\mathrm{AB}\end{array}$ \\
\hline $\begin{array}{l}\text { Gibberellic acid } 75 \mathrm{mg} \mathrm{L}^{-1}+ \\
\text { Nitrogreen fertilizer } 4 \mathrm{ml} \mathrm{L}^{-1}\end{array}$ & $\begin{array}{c}50.34 \\
\mathrm{~A}\end{array}$ & $\begin{array}{c}3.87 \\
\mathrm{~A}\end{array}$ & $\begin{array}{c}48.52 \\
\mathrm{~A}\end{array}$ & $\begin{array}{l}47.88 \\
\mathrm{AB}\end{array}$ \\
\hline $\begin{array}{l}\text { Gibberellic acid } 75 \mathrm{mg} \mathrm{L}^{-1}+ \\
\text { Nutrigreen fertilizer } 6 \mathrm{ml} \mathrm{L}^{-1}\end{array}$ & $\begin{array}{c}52.10 \\
\mathrm{~A}\end{array}$ & $\begin{array}{c}3.98 \\
\mathrm{~A}\end{array}$ & $\begin{array}{c}49.11 \\
\mathrm{~A}\end{array}$ & $\begin{array}{c}46.14 \\
\mathrm{AB}\end{array}$ \\
\hline $\begin{array}{l}\text { Gibberellic acid } 100 \mathrm{mg} \mathrm{L}^{-1}+ \\
\text { Nutrigreen fertilizer } 2 \mathrm{ml} \mathrm{L}^{-1}\end{array}$ & $\begin{array}{c}51.85 \\
\mathrm{~A}\end{array}$ & $\begin{array}{c}3.70 \\
\mathrm{~A}\end{array}$ & $\begin{array}{c}53.53 \\
\mathrm{~A}\end{array}$ & $\begin{array}{c}49.69 \\
\mathrm{AB}\end{array}$ \\
\hline $\begin{array}{l}\text { Gibberellic acid } 100 \mathrm{mg} \mathrm{L}^{-1}+ \\
\text { Nutrigreen fertilizer } 4 \mathrm{ml} \mathrm{L}^{-1}\end{array}$ & $\begin{array}{c}50.86 \\
\mathrm{~A}\end{array}$ & $\begin{array}{c}4.09 \\
\text { A }\end{array}$ & $\begin{array}{c}54.21 \\
\mathrm{~A}\end{array}$ & $\begin{array}{c}52.06 \\
\mathrm{~A}\end{array}$ \\
\hline $\begin{array}{l}\text { Gibberellic acid } 100 \mathrm{mg} \mathrm{L}^{-1}+ \\
\text { Nutrigreen fertilizer } 6 \mathrm{ml} \mathrm{L}^{-1}\end{array}$ & $\begin{array}{l}49.16 \\
\text { A }\end{array}$ & $\begin{array}{c}4.22 \\
\mathrm{~A}\end{array}$ & $\begin{array}{c}51.94 \\
\text { A }\end{array}$ & $\begin{array}{l}50.92 \\
\text { A }\end{array}$ \\
\hline
\end{tabular}

** The averages followed by different letters and for each attribute indicate the presence of significant differences between them at the 5\% probability level according to the Duncan polynomial test. 


\section{CONCLUSIONS}

We conclude from the results of this study the positive effect of using the levels of gibberellic acid and liquid fertilizer Nutrigreen to improve the characteristics of the vegetative growth of Sour orange seedlings under study, so the study recommends their use in nurseries to obtain strong seedlings and suitable for budding in the shortest possible time.

\section{REFERENCES}

Al-A'areji, J. M; Alalaf A. H. and Shayal Alalam, A. T. (2014). The response of loquat (Eriopotrya japonica Lindi) seedlings to different of sources of liquid organic fertilizers application. J. Kirkuk Univ. Agric. Sci., 5(2): 11-19.

Alalaf, A. H. and Shayal Alala, A. T. (2014). Effect of organic fertilizer Nutrgreen and salicylic acid foliar spray on growth of Fig transplants cvs Aswad Diala and White Adritic. Mesopotamia J. Agric., 42(1): $21-30$.

Alalaf, A. H. (2019). Effect of budding date and Chemical, Organic and bio fertilization on budding success of local orange and subsequent growth of the seedlings. Ph.D. Thesis. Hort. \& Landscape design Dept. College of Agric. \& Forestry, Mosul Univ., Iraq.

Duncan, B. D. (1955). Multiple range and multiple F-tests. Biometrics, 11: 1- 42.

Felixloh, J. G. and Bassuk, N. (2000). Use of the Minolta SPAD-502 to determine chlorophyll concentration in Ficus benjamina L. and Populus deltoids Marsh leaf tissue. HortSci., 35(3): 423.

Hartmann, H.; Kester, D.; Davies, F. and Geneve, R. (2011). Plant propagation: principles and practices (8th edn.). New York: Prentice Hall.

Hopkins, W.G. and Huner, N. P.A. (2005). Introduction of Plant Physiology. $3^{\text {rd }}$ Edition. John Wiley and sons. Inc. USA.
Khaled, H. and Fawy, H. A. (2011). Effect of different levels of humic acids on the nutrient content, plant growth and soil properties under conditions of salinity. Soil \& Water Research, 6(1): 21-29.

Nag, S.; Saha, K. and Choudhuri, M. A. (2001). Role of auxin and polyamines in Adventitious root formation in relation to changes in compounds involved in rooting. J. Plant Growth Regulation, 20: 182-194.

SAS. (2001). SAS/ STAT Users Guide for personal computers, SAS Institute Inc, Cary, N. C. USA.

Singh, B.K. (1999). Plant Amino Acids: Biochemistry and Biotechnology. Marcel Dekker Inc.; New York, USA, 648. 